\title{
MATERNAL AND PERINATAL OUTCOME IN CASES OF PLACENTA PREVIA- AN OBSERVATIONAL RECORD-BASED STUDY IN A TERTIARY CARE HOSPITAL IN JHARKHAND
}

\author{
Kiran Trivedi' ${ }^{1}$ Shashi Bala Singh², Megha Bhagat ${ }^{3}$, Rashmi Kumari $^{4}$
}

${ }_{1}^{1}$ Associate Professor, Department of Obstetrics and Gynaecology, Rajendra Institute of Medical Sciences. ${ }^{2}$ Associate Professor, Department of Obstetrics and Gynaecology, Rajendra Institute of Medical Sciences. ${ }^{3}$ Senior Resident, Department of Obstetrics and Gynaecology, Rajendra Institute of Medical Sciences. ${ }^{4} 2^{\text {nd }}$ Year Junior Resident, Department of Obstetrics and Gynaecology, Rajendra Institute of Medical Sciences.

\section{ABSTRACT}

\section{BACKGROUND}

Placenta previa is an Obstetrical condition with high foetomaternal complication. Placenta previa is found in $1 / 3^{\text {rd }}$ cases of antepartum haemorrhage. This study was conducted to find out demographic profile, maternal and perinatal outcome in cases of Placenta previa in our Institution.

\section{MATERIALS AND METHODS}

This study was done at Rajendra Institute of Medical Sciences in the Department of Obstetrics and Gynaecology (O and G) from January 2013 to December 2016. The cases admitted in Labour room and OPD with period of gestation more than 28 weeks with painless vaginal bleeding or diagnosed as having Placenta previa on routine ultrasonography were included in this study. All antenatal women in this study were evaluated with comprehensive maternal history, clinical, laboratory and ultrasound examination and demographic profile, type of Placenta previa, previous method of delivery and its impact on present pregnancy and mode of delivery along with maternal and perinatal outcome.

\section{RESULTS}

A total of 135 patients with Placenta previa were identified. Two-thirds of women were unbooked. One-half of total patients were between 20 - 25 years. Two-thirds of women were multigravida and $62.22 \%$ patients were multiparous. Type 4 Placenta previa was in $32.59 \%$. There was history of previous surgeries in $49.63 \%$. Half of total patients were admitted at 35 to 37 weeks of gestation. Normal delivery is in $11.11 \%$ cases and 15 babies were still born. A one-third of total babies were admitted in NICU. Three-fifths patients presented with antepartum haemorrhage and one-third patients had postpartum haemorrhage. Morbidly adherent placenta was found in 8 patients (5.92\%) and hysterectomy was done in 12 patients (8.89\%). Balloon tamponade and vaginal packing was done in 8 patients (5.92\%). Blood transfusion was needed in 115 patients (85.18\%). Wound infection, febrile illness and prolonged hospital stay was also found in this study. There was one case of bladder injury (0.74\%) intra-operatively and 2 maternal death $(1.48 \%)$ was found.

\section{CONCLUSION}

Placenta previa causes threat to foetal and maternal health and contribute to significant rise in foetomaternal morbidity and mortality. It is a great challenge to Obstetrician and needs lot of skill and experience to deal with it. Early diagnosis, timely intervention, blood transfusion facility and a team of skilled obstetrician, paediatrician and anaesthetist can improve the outcome.

\section{KEYWORDS}

Maternal, Perinatal, Placenta Previa, Antepartum Haemorrhage, Postpartum Haemorrhage.

HOW TO CITE THIS ARTICLE: Trivedi K, Singh SB, Bhagat M, et al. Maternal and perinatal outcome in cases of placenta previa- an observational record-based study in a tertiary care hospital in Jharkhand. J. Evolution Med. Dent. Sci. 2017;6(44):3411-3414, DOI: $10.14260 /$ Jemds/2017/739

\section{BACKGROUND \\ Placenta previa is a condition where implantation of Placenta occurs in lower uterine segment partially or completely covering the os. It is caused by low implantation of blastocyst in the uterine cavity, but cause of low implantation is unknown. The aetiology remains controversial.}

Financial or Other, Competing Interest: None.

Submission 10-05-2017, Peer Review 23-05-2017,

Acceptance 25-05-2017, Published 01-06-2017.

Corresponding Author:

Dr. Kiran Trivedi,

Rama Nursing Home,

Opposite GEL Church Main Road,

Ranchi-834001,

Jharkhand.

E-mail: trivedikiran2011@gmail.com

DOI: $10.14260 /$ jemds $/ 2017 / 739$

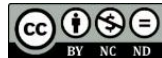

It is hypothesised to be related to abnormal vascularisation of the endometrium caused by scarring or atrophy from previous trauma, surgery or infection.

These factors may reduce differential growth of the lower segment resulting in less upward shift in Placental position as pregnancy advances.[1] The traditional classification of Placenta previa describes the degree of Placenta encroaches upon the cervix in labour and is divided into low lying, marginal, partial or complete Placenta previa.[2] In recent years due to increased value of transvaginal ultrasonography in diagnosis of Placenta previa, the traditional classification is obsolete. Diagnosis is made on history, clinical examination and few investigations that include ultrasound (transabdominal/transvaginal) and Magnetic Resonance Imaging (MRI).[3] The condition is frequently complicated by invasion of Placental villi beyond decidua basalis causing Placenta accreta or increta. 
Several risk factors associated with Placenta previa includes advanced maternal age, previous abortion, previous caesarean section and Placenta previa in previous pregnancy. ${ }^{[4]}$ Myometrial damage due to caesarean section and $\mathrm{D}$ and $\mathrm{C}$ are main predisposing factors. Previous caesarean section is a known risk factor for placenta previa and risk increases with number of caesarean deliveries and previous history of placenta previa.

Most Obstetricians are concerned about massive haemorrhage not only when complete previa exists, but also when placenta is located in the anterior position of the uterus beneath the caesarean site.

Patients of Placenta previa are at increased risk of spontaneous abortions and congenital malformations. It is also associated with antepartum and postpartum haemorrhage leading to increased blood loss. There is high rate of Caesarean section, peripartum hysterectomy and prolonged hospitalisation. Perinatal outcome is also guarded with increased risk of prematurity and high rate of perinatal mortality and morbidity. As the frequency of primary caesarean section is increasing and cases of Placenta previa are consistently rising, so there is need to assess the demographic profile, risk factors and maternal and perinatal outcome in placenta previa.

\section{Aims and Objectives}

This study was conducted to describe epidemiological factors of pregnant mothers who were diagnosed with placenta previa and to find out maternal and perinatal outcome in cases of Placenta previa in a Tertiary Medical Institution of Jharkhand.

\section{MATERIALS AND METHODS}

Descriptive study from January 2013 to December 2016 was conducted in the Department of Obstetrics and Gynaecology of Rajendra Institute of Medical Sciences (RIMS), Ranchi. The patients were admitted in labour room and those admitted from OPD with a period of gestation more than 28 weeks with painless vaginal bleeding or diagnosed as having Placenta previa on routine ultrasonography were included in the study. All patients were evaluated with detailed maternal history, clinical examination, laboratory and radiological investigations. Caesarean section was performed at 37 weeks or if there was any obstetrical indications or any acute episode of bleeding per vaginum. Impact of previous surgeries, present method of delivery, maternal and perinatal complications and need for blood transfusion were noted.

\section{Inclusion Criteria}

All cases of Placenta previa diagnosed by clinical presentation and ultrasonography having gestational age of 28 weeks.

\section{RESULTS}

During the study period, a total of 135 patients of Placenta previa were identified.

In our study, 70 patients (58.85\%) were found in the age group of 20 - 25 years followed by 45 patients $(33.33 \%)$ of age group 26 - 30 years; 12 (8.89\%) of age group $>30$ years and 8 patients $(5.93 \%)$ were belonging to $<20$ years' age group. In our study, maximum patients were multigravida (73.33\%), only 36 patients $(26.67 \%)$ were primigravida. Placenta previa was $62.22 \%$ in multiparous and $26.67 \%$ in nulliparous. Most common type is type 4 with 44 patients (32.59\%) followed by type 1 with 39 patients (28.89\%), type 2 with 32 patients $(23.70 \%)$ and type 3 with 20 patients (14.81\%).

In this study, 67 patients (49.63\%) had history of previous surgeries. In our study 78 patients (57.78\%) were with Cephalic presentation, 32 patients $(23.70 \%)$, transverse lie was in 22 patients $(16.29 \%)$ and 3 patients $(2.22 \%)$ were with unstable lie; 68 patients $(50.37 \%)$ presented with 35 37 weeks of pregnancy, 35 patients $(25.92 \%)$ were with 38 42 weeks of gestation and 32 patients $(23.70 \%)$ were with 28 - 34 weeks of gestation.

\begin{tabular}{|c|c|c|c|}
\hline \multicolumn{2}{|c|}{ Characteristics } & Frequency & Percentage \\
\hline \multirow{2}{*}{$\begin{array}{l}\text { Registration } \\
\text { Status }\end{array}$} & Booked & 31 & $22.96 \%$ \\
\hline & Unbooked & 104 & $77.03 \%$ \\
\hline \multirow{4}{*}{$\begin{array}{l}\text { Age of Pregnant } \\
\text { Female }\end{array}$} & $<20$ years & 8 & $5.9 \%$ \\
\hline & $20-25$ years & 70 & $51.85 \%$ \\
\hline & 26 - 30 years & 45 & $33.33 \%$ \\
\hline & $>30$ years & 12 & $8.88 \%$ \\
\hline \multirow{2}{*}{ Gravida Status } & Primigravida & 36 & $26.66 \%$ \\
\hline & Multigravida & 99 & $73.33 \%$ \\
\hline \multirow{4}{*}{ Parity } & Para 0 & 51 & $37.77 \%$ \\
\hline & Para 1 & 55 & $40.74 \%$ \\
\hline & Para 2 & 18 & $13.33 \%$ \\
\hline & Para $>=3$ & 11 & $8.14 \%$ \\
\hline \multirow{3}{*}{$\begin{array}{c}\text { History of any } \\
\text { Previous } \\
\text { Surgeries }\end{array}$} & Previous 1 CS & 40 & $29.62 \%$ \\
\hline & Previous 2 CS & 12 & $8.88 \%$ \\
\hline & $\mathrm{D}$ and $\mathrm{E}$ & 15 & $11.11 \%$ \\
\hline \multirow{3}{*}{$\begin{array}{c}\text { Period of } \\
\text { Gestation at } \\
\text { Time of } \\
\text { Admission }\end{array}$} & $28-34$ wks & 32 & $23.70 \%$ \\
\hline & $35-37$ wks & 68 & $50.37 \%$ \\
\hline & $38-42$ wks & 35 & $25.92 \%$ \\
\hline \multirow{4}{*}{$\begin{array}{l}\text { Type of Placenta } \\
\text { Previa }\end{array}$} & Low Lying & 39 & $28.89 \%$ \\
\hline & Marginal & 32 & $23.70 \%$ \\
\hline & $\begin{array}{c}\text { Incomplete } \\
\text { Central Previa }\end{array}$ & 20 & $14.81 \%$ \\
\hline & \begin{tabular}{|c|} 
Complete Central \\
Previa
\end{tabular} & 44 & $32.59 \%$ \\
\hline \multirow{4}{*}{$\begin{array}{l}\text { Presentation of } \\
\quad \text { Foetus }\end{array}$} & \begin{tabular}{|l|} 
Cephalic \\
\end{tabular} & 78 & $57.78 \%$ \\
\hline & Breach & 32 & $23.7 \%$ \\
\hline & Transverse Lie & 22 & $16.29 \%$ \\
\hline & \begin{tabular}{|l|} 
Unstable Lie \\
\end{tabular} & 3 & $2.22 \%$ \\
\hline \multicolumn{4}{|c|}{$\begin{array}{c}\text { Table 1. Occurrence of Placenta Previa among Patients } \\
\text { in Relation to Baseline Characteristics }(n=135)\end{array}$} \\
\hline
\end{tabular}

\begin{tabular}{|c|c|c|c|}
\hline \multirow{2}{*}{$\begin{array}{l}\text { Mode of } \\
\text { Delivery }\end{array}$} & Vaginal Delivery & 15 & $11.11 \%$ \\
\hline & LSCS & 120 & $88.89 \%$ \\
\hline \multirow{2}{*}{$\begin{array}{l}\text { Perinatal } \\
\text { Outcome }\end{array}$} & Still Birth & 15 & $11.11 \%$ \\
\hline & Live Birth & 120 & $88.89 \%$ \\
\hline \multirow{4}{*}{$\begin{array}{c}\text { Weight of } \\
\text { Baby }\end{array}$} & $<2 \mathrm{~kg}$ & 42 & $31.11 \%$ \\
\hline & $2-2.5 \mathrm{~kg}$ & 52 & $38.52 \%$ \\
\hline & $2.6-3 \mathrm{~kg}$ & 34 & $25.18 \%$ \\
\hline & $>3 \mathrm{~kg}$ & 7 & $5.18 \%$ \\
\hline \multicolumn{4}{|c|}{$\begin{array}{l}\text { Table 2. Perinatal Outcome of Patient associated } \\
\text { with Placenta Previa }(n=135)\end{array}$} \\
\hline
\end{tabular}

Babies were delivered by caesarean section of 120 patients (88.89\%), while 15 patients (11.11\%) were delivered vaginally. 
Thirty-eight babies (28.15\%) were admitted in NICU, out of which 10 babies died due to prematurity and its complications. Fifteen babies (11.11\%) were still born.

\begin{tabular}{|c|c|c|c|}
\hline \multirow{1}{*}{} & $\begin{array}{c}\text { Antepartum } \\
\text { Haemorrhage }\end{array}$ & 82 & $60.74 \%$ \\
\cline { 2 - 4 } & $\begin{array}{c}\text { Postpartum } \\
\text { Haemorrhage }\end{array}$ & 42 & $31.11 \%$ \\
\cline { 2 - 4 } & Maternal Anaemia & 70 & $51.85 \%$ \\
\cline { 2 - 4 } $\begin{array}{c}\text { Cervicoisthmic } \\
\text { Sutures }\end{array}$ & 8 & $5.92 \%$ \\
\cline { 2 - 4 } $\begin{array}{c}\text { Maternal } \\
\text { B-Lynch Sutures }\end{array}$ & $\begin{array}{c}\text { Balloon } \\
\text { Tamponade/ } \\
\text { Vaginal Packing }\end{array}$ & 8 & $5.92 \%$ \\
\cline { 2 - 4 } & $\begin{array}{c}\text { Obstetric } \\
\text { Hysterectomy }\end{array}$ & 12 & $8.89 \%$ \\
\cline { 2 - 4 } & Febrile Illness & 15 & $11.11 \%$ \\
\cline { 2 - 4 } & Wound Infection & 10 & $7.40 \%$ \\
\cline { 2 - 4 } & Bladder Injury & 1 & $0.74 \%$ \\
\cline { 2 - 4 } & $\begin{array}{c}\text { Prolonged Hospital } \\
\text { Stay }\end{array}$ & 32 & $23.70 \%$ \\
\cline { 2 - 4 } & $\begin{array}{c}\text { Need Blood } \\
\text { Transfusion }\end{array}$ & 115 & $85.18 \%$ \\
\hline \multirow{1}{*}{$\begin{array}{c}\text { Table 3. Maternal Complication associated with } \\
\text { Placenta Previa among Patient (n = 135) }\end{array}$} \\
\hline
\end{tabular}

There were 2 maternal mortality in our study group (1.48\%); 115 patients (85.18\%) needed blood transfusion in our study group.

\section{DISCUSSION}

The present study was undertaken to access foetomaternal outcome in patients of Placenta previa from January 2013 to December 2016. Our Institute is a Tertiary Referral Centre, so we get referred cases from all areas of Jharkhand. In our study, 104 patients were unbooked $(77.03 \%)$ which was responsible for late detection of cases. In our study, maximum number of patients belonged to age group $20-25$ years $(51.85 \%)$ and $26-30$ years $(33.33 \%)$. It denotes that maximum number of patients were below 30 years of age, which is comparable to study by Kaur B,[5] Zhang J, Savitz D, in 1993 shows that incidence of Placenta previa increases with maternal age.[6] Placenta previa was found more commonly in multiparous women than nulliparous women. The results of our study are comparable to the study by Faiz et al.[1] Previous surgeries like caesarean section, D and E are proven risk factors as reported in different studies and it is also found in the present study. ${ }^{[7,8]}$ In our study, 67 patients $(49.63 \%)$ had history of previous surgeries and 12 cases (8.89\%) had Caesarean Hysterectomy usually due to decreased contractility of scarred lower segment leading to postpartum haemorrhage in 4 cases $(2.96 \%)$ and morbidly adherent Placenta (5.92\%).[9] In our study 78 patients had cephalic presentation (57.78\%), while others were noncephalic (Breech, Transverse lie and Unstable lie).[10] Out of 135 patients, 120 patients (88.89\%) were delivered by Caesarean section and rest delivered vaginally.

Babies born between 28 - 34 weeks is 32 babies (23.70\%), 68 babies (50.37\%) were born between $35-37$ weeks of gestation and 35 (25.92\%) babies were born between 38 - 42 weeks of gestation. Thirty-eight babies were admitted in NICU with body weight less than $2 \mathrm{~kg}$. Out of them, 10 babies (7.40\%) died in NICU due to prematurity and its complications.

In our study 82 patients (60.74\%) presented with antepartum haemorrhage, 42 patients (31.11\%) had postpartum haemorrhage, 70 patients $(51.85 \%)$ had anaemia, 12 patients $(8.89 \%)$ had emergency Obstetric Hysterectomy which were due to morbidly adherent placenta ( 8 patients) and due to intractable haemorrhage ( 4 patients). There was one case of bladder injury in case of Placenta accreta intraoperatively. Haemorrhage was more in scarred cases with anterior placenta previa. In our study 115 patients $(85.18 \%)$ received blood transfusion, in which 20 patients (14.81\%) received more than 4 units of blood transfusion. In our study, atonic PPH was found in significant number of patients $(31.11 \%)$ and they were treated vigorously with oxytocin and other uterotonics, balloon tamponade and additional sutures like B-Lynch and cervicoisthmic sutures. In our study 2 patients died due to irreversible haemorrhagic shock due to compromised status at time of admission.

\section{CONCLUSION}

Placenta previa is a great challenge to every Obstetrician due to high risk of maternal and perinatal complications. Thus, good antenatal check-up, correction of anaemia and timely diagnosis by ultrasonography and referral to tertiary care centre with blood bank facility and good NICU setup, skilled Obstetrician and efficient team of anaesthetist are the key factors for successful maternal and foetal outcome. As previous surgery is a proven risk factor for Placenta previa, so liberalisation of caesarean section should be stopped. Unintended pregnancy can be prevented by contraceptive use, as multiparity and D and E are also known risk factors for Placenta previa.

\section{REFERENCES}

[1] Faiz AS, Ananth CV. Etiology and risk factors for placenta previa: an overview and meta-analysis of observational studies. J Matern Fetal Neonatal Med 2003;13(3):175-90.

[2] Oppenheimer L. Society of obstetrician and gynaecologist of Canada. Diagnosis and management of placenta previa. J Obstet Gynaecol Can 2007;29(3):261-73.

[3] Razia A, Aliya B, Ashma G, et al. Frequency of placenta previa with previous caesarean section. Ann King Edward Med Coll 2005;1:299-300.

[4] Hung TH, Hsieh CC, Hsu JJ, et al. Risk factors for placenta previa in an Asian population. Int J Gynaecol Obst 2007;97(1):26-30.

[5] Kaur B, Dhar T, Sohi I. Incidence risk factor and neonatal outcomes of placenta previa presenting as antepartum haemorrhage in tertiary care centre of North India. International Journal of Basic and Applied Medical Sciences 2015;5(3):58-61.

[6] Zhang J, Savitz DA. Maternal age and placenta previa: a population-based, case-control study. Am J Obstet Gynaecol 1993;168(2):641-5.

[7] Lavender T, Hofmeyr GJ, Neilson JP, et al. Caesarean section for non-medical reasons at term. Cochrane Database Syst Rev 2012;3:CD004660. 
[8] Karlstrom A, Nystedt A, Hildingsson I. A comparative study of the experience of childbirth between women who preferred and had a caesarean section and women who preferred and had a vaginal birth. Sex Reprod Healthc 2011;2(3):93-9.

[9] Wolf EJ, Mallozzi A, Rodis JF, et al. Placenta previa is not an independent risk factor for a small for gestational age infant. Obstet Gynecol 1991;77(5): 707-9.
[10] Zaki ZM, Bahar AM, Ali ME, et al. Risk factors and morbidity in patients with placenta previa accreta compared to placenta previa non-accreta. Acta Obstect Gynaecol Scand 1998;77(4):391-4. 